\title{
Studying the Effective Factors of Investors' Sensitivity towards Performance and Price of Investment Funds in Tehran Stock Exchange
}

\author{
Dr. Alireza Zareei \\ Department of Management and Accounting, Mobarakeh Branch, Islamic Azad University, \\ Mobarakeh, Iran
}

\section{Davoud Gholami Siahboumi}

Department of Management and Accounting, Mobarakeh Branch, Islamic Azad University, Mobarakeh, Iran

DOI: $\quad 10.6007 /$ IJARBSS/v4-i4/782 URL: http://dx.doi.org/10.6007/IJARBSS/v4-i4/782

\begin{abstract}
Considering that the investment funds in Tehran Stock Exchange started their activity during the last five years and tendency of real and legal investors to invest in such funds, studying the relationship between goodwill and ranking of funds as effective factors on investors' sensitivity towards performance and price of investment funds has been focused in this study. Therefore, twenty two and thirty six funds were investigated in 2011 and 2012 respectively. The ranking factor is in the form of two variables of high ranking and low ranking as well as four factors under study as four representatives of goodwill including inter-group ranking score of funds, size, the fund's age and bank.

Data analysis was conducted through cross-functional structure with fixed effects and ordinary least squares (OLS) method. The results confirm the significant linear relationship among the variables of fund age, bank and inter-group ranking score with investors' sensitivity towards price. This relationship was just confirmed between investors' sensitivity towards performance with fund age and bank variables. Also, the relationship between ranking of funds and investors' sensitivity towards performance and price of funds has been confirmed.
\end{abstract}

\section{Introduction}

The number of the investment funds has been increased annually since 2008 when these funds were launched through the license given by Karafarin Bank following the desire of the authorities of the stock market in Iran and its startup in 2009. Now there are more than 80 funds in Tehran Stock Exchange that is the symbol of capital market in Iran

The investment funds have been appeared in England in $18^{\text {th }}$ century; but growth and development of the funds in the modern form dates back to 1924 in Boston, US. In Iran, these funds are similar to those existing in other countries in many respects and in some cases they are different. Most differences are related to the administration manner of funds and their diversification in other countries. Funds have units of investment that are purchased by investors or are sold to the fund itself. This kind of buying and selling that is different from 
stock trading of the investment companies is referred to as issuance and revocation of the unit of investment. There is no second hand market to issue and revoke the units of investment and whenever the investor wants to sell his/her units, the fund should revoke its unit of investment and the fund's guarantor should return the intended cash to the investor. Price of each unit of the fund is determined with the Fund's NAV at the end of the day after the stock exchange is closed. In order to enter the fund, the investor refers to the investment fund (visually, virtually or through telephone call) and requests for issuance of a unit of investment or revocation of his/her units if he/she wants to exit the fund. The investment funds have variable capital and demand level of issuance and revocation of the unit of investment changes their capital level. This is different for the investment companies whose capital is increased through certain legal formalities.

\section{Theoretical framework}

To calculate the investors' sensitivity, first the investment flows should be calculated. Net investment flow is obtained via the following relation (Gil-Bazo \& Ruiz-Verd, 2009):

Flow $_{\text {it }}=\left[\right.$ TNA $_{\text {it }}-$ TNA $\left._{i t-1}\left(1+r_{i t}\right)\right] /$ TNA $_{i t-1}$

In this equation, Flow it is net investment flow of fund $i$ in period $t$; TNA is net sum of assets of the fund and net purchases and sales is calculated at the end of day; $r_{i t}$ is return rate of the fund $i$ or performance in day $t$ in comparison with the previous day that is obtained through the following relation (Saeidi et al., 2011):

ri $=$ (NAVit - NAVit-1) / NAVit-1

Then, the measurement model of investment flow should be proposed based on the effective factors on investors' sensitivity (Navone, 2012). By investors' sensitivity, we mean the changes created in investment flows due to the changes in the intended factors. When an investor wants to invest in a fund, he/she considers some factors given to his/her individual characteristics and time requirements and evaluates certain standards. Performance or return rate of previous period(s), loads paid for entering the fund or exiting it, the fund's background, ranking status of the fund among other funds at present and in previous periods, liquidity of the fund and its average value, rewards paid to the managers and so on are the most important standards that are considered by investors at the investment time or when they exit the fund. Investors show less sensitivity towards some of these standards and perhaps they have more sensitivity towards some other. The investor who believes that rewards of managers are a negative factor in earning the fund's return shows more sensitivity towards the fund's price. A major part of this price is composed of employment expenses of the manager. In contrast, another group of investors believe that rewards of managers are directly related to the fund's return. Professional rewards are for professional managers and earning the highest returns depends on employment of professional managers. Therefore, this group of investors should have less sensitivity towards the fund's price or cost ratios but more sensitivity towards the fund's performance and gaining high rankings. Another component of cost ratios is brokerage load fund that the fund receives from the investor when he/she enters or exits. The investor's consecutive entering and exiting means to lose one part of his/her capital as brokerage load. Degree of sensitivity of investors towards such seemingly insignificant prices has a direct effect on investment flows (Wilcox, 2003). In order to maintain their investors, the funds decrease back-end loads with regard to the number of years of maintaining the units of investment by 
the investor so that if an investor has maintained a unit of investment for seven years, he/she is dispensed with payment of loads. This can be very vital for that group of investors who have more sensitivity towards external load payment and the load to enter another fund that is led to maintenance of their investment. The conducted studies (Navone, 2012; Christoffersen, 2007) indicated that many investors act unprofessionally and are deceived by the exaggeration and goodwill of funds and indemnify the misprofessionalism of funds' managers.

\section{Research background}

Navone (2012) in a comprehensive study showed that sensitivity of investors towards performance and price of funds is related differently to the fund's goodwill. Also he documented while sensitivity of investors towards performance is increased monotonously with the previous performance, their sensitivity towards price is not the same.

Gil-Bazo and Ruiz-Verd (2009) tried to explain the negative relationship between high performance and cost ratios and finally concluded that the funds with the expected lower performance are classified as higher cost funds which are the target of performance sensitivity of investors. Also, performance sensitivity indicates price sensitivity.

Choi et al. (2007) have concluded that investors do not consider costs simply as a negative element of gross yield and they evaluate previous performance and cost ratios separately when choosing a company. Evidences reveal that relative importance of these two information elements, i.e. previous performance and cost ratios are different among the investors and structural factors of population such as age, gender, education and training are effective on it. Huang et al. (2007) concluded that if costs of searching for information and information availability are effective on how investors react towards previous performance, it has a stronger effect on the expected sensitivity of investors towards price.

Wilcox (2003) conducted an empirical study and represented various investment portfolios to 50 consumers and asked them to choose the highest performances of the fund. He showed that investors pay less attention to costs than performance standards and there is an important relationship between management expenses with ratio of previous performance that is highly affected by population indexes. Being wealthy, high education level and high financial understanding of investors can be referred to as the population indexes and finally previous performance is more important then the cost.

In a research about the relationship between gross performance of the fund and the price paid by investors, Musto and Christoffersen (2002) documented a negative relationship. They concluded that the stock of funds with low quality performance is purchased by those who have less sensitivity towards performance. In contrast, with regard to higher level funds in terms of performance, the stock is purchased by those who have more sensitivity towards performance. This is while there are reverse sensitivities towards cost.

Saeidi and Saeidi (2011) concluded that there is a significant correlation between cash flow of funds and market return. This correlation is stronger for capital inflow towards capital outflow and net flow. Similarly, no evidences were found in monthly data analysis regarding that the current or market return has a significant effect on capital flow. About non-simultaneous relations, the process of revocation follows an interval preceding the market return. Also they studied weekly information and documented that the cash flow of funds is affected by market 
return unlike monthly time intervals. Investors in investment funds react positively towards market return.

Saeidi et al. (2011) examined 20 funds in a study and investigated the effects of ten factors. Then they confirmed a significant linear relationship among six variables including market return, growth rate of fund value, absolute value of deviation from average fund return, value of issuing the units of investment, ratio of fund's activity, issuance value of the units of investment with return of investment funds and showed that there is a relationship among market return, risk, ratio of activity, capital and return of the previous period with fund's return.

According to Pourzamani et al. (2011), there is a positive and significant correlation among fluctuations of the fund return up to previous period, return of the fund's previous period, fund's age, rate of assets turnover under the fund's management up to the previous period and the return earned by fund. Also evidences indicated that there is a significant difference among properties managed by the fund in the previous period, fund costs, growth rate of new money with regard to previous period and fund return.

\section{Hypotheses}

The hypotheses are as follows:

Hypothesis 1: Goodwill is effective on sensitivity of investors towards the fund's price. Hypothesis 2: Goodwill is effective on sensitivity of investors towards the fund's performance. Hypothesis 3: Fund ranking is effective on sensitivity of investors towards the fund's price. Hypothesis 4: Fund ranking is effective on sensitivity of investors towards the fund's price. In the following, research models are presented; independent variables are introduced and it is explained why relations among the variables are predicted as research hypotheses.

The below model has been proposed to show the relationship among investment flows and the variables under study and calculate the investment flows.

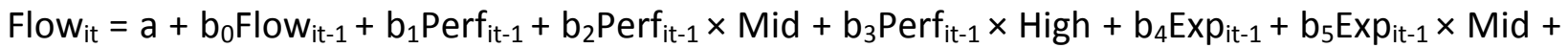
$\mathrm{b}_{6}$ Exp $_{\mathrm{it}-1} \times$ High $+\mathrm{c}_{11}$ Perf $_{\mathrm{it}-1} \times$ size $+\mathrm{c}_{12}$ Perfi $_{\mathrm{t}-1} \times$ age $+\mathrm{c}_{13}$ Perf $_{\mathrm{it}-1} \times$ bank $+\mathrm{c}_{14}$ Perf $_{\text {it- } 1} \times$ iccat + $c_{21} \operatorname{Exp}_{\text {it- } 1} \times$ size $+c_{22} \operatorname{Expi}_{\text {t-1 }} \times$ age $+\mathrm{c}_{23} \operatorname{Exp}_{\text {it-1 }} \times$ bank $+c_{24} \operatorname{Exp}_{\text {it1 }} \times$ iccat $+c_{31}$ size $\times$ Mid $+\mathrm{c}_{32}$ age $\times$ Mid $+\mathrm{C}_{33}$ bank $\times$ Mid $+\mathrm{C}_{34}$ iccat $\times$ Mid $+\mathrm{C}_{41}$ size $\times$ High $+\mathrm{C}_{42}$ age $\times$ High $+\mathrm{C}_{43}$ bank $\times$ High $+\mathrm{C}_{44}$ iccat $\times$ High $+\mathrm{d}_{1} \times$ Mid $+\mathrm{d}_{2} \times$ High $+\varepsilon_{\mathrm{it}-1}$

The model is generalized based on performance, cost ratios of the fund, high and low ranking variables of the fund and four criterions of goodwill, i.e. bank, inter-group ranking, size and age. In order to increase accuracy, interaction of each variable is included in the model too.

PERF-sens $i$ : sensitivity of the investor towards fund's performance $i$ in period $t$ via derivation of the measurement model of investment flow with regard to performance (perf)

PRIC-sens it $_{\text {: }}$ sensitivity of the investor towards fund's price $i$ in period $t$ via derivation of the measurement model of investment flow with regard to price (pric)

Perf $_{\text {it-1 }}$ : performance or return of fund $i$ in period $t-1$

$\left(\mathrm{NAV}_{\text {it }}-\mathrm{NAV} \mathrm{V}_{\text {it- } 1}\right) / \mathrm{NAV}_{\text {it-1 }}$

where NAV is net value of fund assets that is calculated monthly.

Exp $_{\text {it-1 }}$ : price or cost ratios of fund $i$ in period $t-1$

It is current costs of the fund that includes employment expenses of the fund's manager, administrative expenditure, front-end loads and back-end loads with a slight difference in funds 
and exists in periodical and annual financial statements of funds. It is obtained through dividing sum of the above-mentioned costs by net properties.

Mid: Symbol of low rank fund

It is a dummy variable that if the fund is ranked in bottom one-third of ranking, it will be equal to 1; otherwise, it will be equal to zero. This variable shows funds with low ranking. Ranking is done annually.

High: Symbol of high rank fund

It is a dummy variable that if the fund is ranked in upper one-third of ranking, it will be equal to 1; otherwise, it will be equal to zero. This variable shows role of the funds with high ranking. Ranking is done annually.

Size: It is natural logarithm of assets under management that is calculated monthly (the last day of each month is the criterion for calculation).

Age: It is natural logarithm of fund's age that is calculated daily until the end of each month.

Bank: It is a dummy variable that if the fund's name is accompanied by the name of a public or private bank at the beginning or ending, it will be equal to 1; otherwise, it will be equal to zero that is fixed during the research period.

Iccat: inter-group ranking

It is a weighted score and a number between zero to ten and is related to ranking of each fund that is calculated annually through its specific calculations.

To calculate sensitivity of investors towards performance and price (cost ratios), derivation of the above model is calculated separately with regard to each factor of high and low ranking and four representatives of goodwill. The four following models are obtained which are used for testing of hypotheses.

Price-sens $_{i t}=\beta_{0}+\beta_{1}$ size $_{i t}+\beta_{2}$ age $_{i t}+\beta_{3}$ bank $_{i t}+\beta_{4}$ iccat $_{i t}+\varepsilon_{i t}$

This model was proposed to test the first hypothesis and is the derivation of the primary model of investment flow with regard to price factor (cost ratios) and measures sensitivity of investors towards price in relation to the fund's goodwill.

Perf-sens $_{i t}=\beta_{0}+\beta_{1}$ size $_{i t}+\beta_{2}$ age $_{i t}+\beta_{3}$ bank $_{i t}+\beta_{4}$ iccat $_{i t}+\varepsilon_{i t}$

This model was proposed to test the second hypothesis and is the derivation of the primary model of investment flow with regard to performance and measures sensitivity of investors towards performance in relation with the fund's goodwill.

Price-sens ${ }_{\text {it }}=\beta_{0}+\beta_{1}$ MID $_{\text {it }}+\beta_{2}$ High $_{\text {it }}+\varepsilon_{\text {it }}$

This model was proposed to test the third hypothesis and is the derivation of the primary model of investment flow with regard to price factor (cost ratios) and measures sensitivity of investors towards price in relation with high and low ranking.

Pref-sens ${ }_{\text {it }}=\beta_{0}+\beta_{1}$ MID $_{\text {it }}+\beta_{2}$ High $_{\text {it }}+\varepsilon_{\text {it }}$

This model was proposed to test the fourth hypothesis and is the derivation of the primary model of investment flow with regard to performance and measures sensitivity of investors towards performance in relation with high and low ranking.

\section{Statistical population and sample}

The statistical population included all investment funds which have activity license from the Stock Exchange Company and were permanently active in 2011 and 2012. Monthly time periods 
were used and the data were collected cross-functionally and separately for 12 months in 2011 and 2012. Then data were studied and the results of both years were compared.

Thus, the number of funds in 2011 was equal to 22 and in 2012 was equal to 36 funds. The number of observations in 2011 and 2012 was equal to 264 and 432 respectively (name of the funds are displayed in Table 1, the first 22 funds were tested in 2011 and all 36 funds were tested in 2012).

\section{Testing of hypotheses}

Testing hypothesis 1

Hypothesis 1: Goodwill is effective on sensitivity of investors towards the fund's price.

Results of data analysis are shown in below tables:

\begin{tabular}{|c|c|c|c|c|c|}
\hline Year & Variable & Coefficient & Standard deviation & t-statistic & Error level \\
\hline \multirow{7}{*}{2012} & Constant coefficient & -587.75 & 8.20 & -71.66 & 0.000 \\
\hline & Size & 97.72 & 32.01 & 3.05 & 0.000 \\
\hline & Age & 67.80 & 4.69 & 14.45 & 0.000 \\
\hline & Bank & 275.23 & 1.45 & 189.69 & 0.000 \\
\hline & Ranking score & 118.73 & 0.58 & 204.93 & 0.000 \\
\hline & $\begin{array}{ll}\text { Coefficient } & \text { of } \\
\text { determination }\end{array}$ & 0.87 & \multicolumn{2}{|c|}{ F-statistic } & 3699.4 \\
\hline & $\begin{array}{l}\text { Adjusted coefficient } \\
\text { of determination }\end{array}$ & 0.85 & \multicolumn{2}{|c|}{ Prob (F-statistic) } & 0.000 \\
\hline
\end{tabular}

\begin{tabular}{|c|l|c|c|c|c|}
\hline Year & \multicolumn{1}{|c|}{ Variable } & Coefficient & Standard deviation & t-statistic & Error level \\
\hline \multirow{5}{*}{2011} & Constant coefficient & -3284.1 & 176.79 & -18.58 & 0.000 \\
\cline { 2 - 6 } & Size & -64.99 & 2.62 & -24.79 & 0.000 \\
\cline { 2 - 6 } & Age & 1055.9 & 65.85 & 16.04 & 0.000 \\
\cline { 2 - 6 } & Bank & 1088.8 & 19.28 & 56.47 & 0.000 \\
\cline { 2 - 6 } & $\begin{array}{l}\text { Ranking score } \\
\text { Coefficient } \\
\text { determination }\end{array}$ & 178.81 & 831 & 21.53 & 0.000 \\
\cline { 2 - 6 } & $\begin{array}{l}\text { Adjusted coefficient } \\
\text { of determination }\end{array}$ & 0.75 & \multicolumn{2}{|c}{ Prob (F-statistictic) } & 0.000 \\
\hline
\end{tabular}


Given to the obtained error level for $\mathrm{F}$ statistic for the two years that is close to zero, $\mathrm{HO}$ is rejected and it shows that regression coefficients are not equal to zero simultaneously. Therefore, there is a relationship among independent variables and the dependent variable simultaneously.

Value of error level for four variables of size, age, bank and ranking score that are representatives of goodwill is close to zero in 2011 and 2012 and is less than error level 0.05. Value of adjusted $\mathrm{R}^{2}$ is equal to 0.75 and 0.85 respectively that shows the independent variable explained $75 \%$ and $85 \%$ of changes of the dependent variable. Considering the positive coefficient of age, bank and ranking score in both years, hypothesis 1 is confirmed about these three variables. But coefficient of size variable in 2011 is negative and in 2012 is positive. Hence, hypothesis 1 is rejected due to unreliability of relationship about size variable. In other words, age, bank and ranking score are effective on sensitivity of investors towards price (cost ratios) in the scope of research.

\begin{tabular}{|c|c|c|c|c|c|}
\hline Year & Variable & Coefficient & Standard deviation & t-statistic & $\begin{array}{l}\text { Error } \\
\text { level }\end{array}$ \\
\hline \multirow{7}{*}{2011} & $\begin{array}{l}\text { Constant } \\
\text { coefficient }\end{array}$ & 710.43 & 9.74 & 72.96 & 0.000 \\
\hline & Size & -13.33 & 0.07 & -201.58 & 0.000 \\
\hline & Age & -262.74 & 1.32 & -198.44 & 0.000 \\
\hline & Bank & -67.92 & 3.17 & -21.45 & 0.000 \\
\hline & Ranking score & 5.13 & 1.62 & 3.16 & 0.000 \\
\hline & $\begin{array}{l}\text { Coefficient } \\
\text { determination }\end{array}$ & 0.69 & \multicolumn{2}{|c|}{ F-statistic } & 9619.7 \\
\hline & $\begin{array}{l}\text { Adjusted } \\
\text { coefficient } \\
\text { determination }\end{array}$ & 0.68 & \multicolumn{2}{|c|}{ Prob (F-statistic) } & 0.000 \\
\hline
\end{tabular}

\begin{tabular}{|c|l|c|c|c|c|}
\hline Year & \multicolumn{1}{|c|}{ Variable } & Coefficient & $\begin{array}{l}\text { Standard } \\
\text { deviation }\end{array}$ & t-statistic & Error level \\
\hline \multirow{2}{*}{} & $\begin{array}{l}\text { Constant } \\
\text { coefficient }\end{array}$ & -587.75 & 8.20 & -71.66 & 0.000 \\
\cline { 2 - 6 } & Size & 97.72 & 32.01 & 3.05 & 0.000 \\
\cline { 2 - 6 } & Age & 67.80 & 4.69 & 14.45 & 0.000 \\
\hline
\end{tabular}




\begin{tabular}{|c|l|c|c|c|c|}
\hline \multirow{2}{*}{2012} & Bank & 275.23 & 1.45 & 189.69 & 0.000 \\
\cline { 2 - 5 } & Ranking score & 118.73 & 0.58 & 204.93 & 0.000 \\
\cline { 2 - 5 } & $\begin{array}{l}\text { Coefficient of } \\
\text { determination }\end{array}$ & 0.87 & F-statistic & 3699.4 \\
\cline { 2 - 6 } $\begin{array}{l}\text { Adjusted of } \\
\text { coefficient } \\
\text { determination }\end{array}$ & 0.85 & Prob (F-statistic) & 0.000 \\
\hline
\end{tabular}

Testing hypothesis 2

The second hypothesis is as below:

Hypothesis 2: Goodwill is effective on sensitivity of investors towards the fund's performance. Given to the obtained error level for $\mathrm{F}$ statistic for the two years that is close to zero, $\mathrm{HO}$ is rejected and it shows that regression coefficients are not equal to zero simultaneously. Therefore, there is a relationship among all independent variables and the dependent variable simultaneously.

Value of error level for four variables of size, age, bank and ranking score that are representatives of goodwill is close to zero in 2011 and 2012 and is less than error level 0.05. However, coefficient of size variable in 2012 has been changed than the one in 2011 and it has become positive. Also, coefficient of ranking score in 2012 has become negative. Thus, hypothesis 2 is rejected due to unreliability of relationship about the two variables. It only is confirmed about age and bank variables. In other words, age and bank variables are effective on sensitivity of investors towards fund's performance in the scope of research. Value of adjusted $R^{2}$ is equal to 0.68 and 0.85 respectively that shows the independent variable explained $68 \%$ and $85 \%$ of changes of the dependent variable.

Testing hypothesis 3

The third hypothesis is as below:

Hypothesis 3: Fund ranking is effective on sensitivity of investors towards the fund's price.

\begin{tabular}{|c|c|c|c|c|c|}
\hline Year & Variable & Coefficient & Standard deviation & t-statistic & Error level \\
\hline \multirow{5}{*}{2011} & $\begin{array}{l}\text { Constant } \\
\text { coefficient }\end{array}$ & 574.28 & 44.41 & 12.93 & 0.000 \\
\hline & Low & 356.03 & 11.30 & 31.51 & 0.000 \\
\hline & High & 917.19 & 44.00 & 20.84 & 0.000 \\
\hline & \multicolumn{2}{|c|}{ Coefficient of determination } & 0.59 & F-statistic & 186.2 \\
\hline & \multicolumn{2}{|c|}{ determination } & 0.58 & $\begin{array}{l}\text { Prob (F- } \\
\text { statistic) }\end{array}$ & 0.000 \\
\hline
\end{tabular}




\begin{tabular}{|c|c|c|c|c|c|}
\hline Year & Variable & Coefficient & Standard deviation & t-statistic & Error level \\
\hline \multirow{5}{*}{2012} & $\begin{array}{l}\text { Constant } \\
\text { coefficient }\end{array}$ & 145.78 & 3.85 & 37.74 & 0.000 \\
\hline & Low & 280.79 & 1.16 & 241.66 & 0.000 \\
\hline & High & 322.93 & 6.59 & 48.99 & 0.000 \\
\hline & \multicolumn{2}{|c|}{ Coefficient of determination } & 0.87 & F-statistic & 5425.4 \\
\hline & \multicolumn{2}{|c|}{$\begin{array}{l}\text { Adjusted coefficient of } \\
\text { determination }\end{array}$} & 0.86 & $\begin{array}{l}\text { Prob (F- } \\
\text { statistic) }\end{array}$ & 0.000 \\
\hline
\end{tabular}

Given to the obtained error level for $\mathrm{F}$ statistic for the two years that is close to zero, $\mathrm{HO}$ is rejected and it shows that regression coefficients are not equal to zero simultaneously. Therefore, there is a relationship among independent variables and the dependent variable simultaneously.

Error level of t-statistic for two variables of Mid and High that indicates fund ranking is close to zero in 2011 and 2012 and is less than error level 0.05 . Value of adjusted $R^{2}$ is equal to 0.30 and 0.49 respectively that shows the independent variable explained $30 \%$ and $49 \%$ of changes of the dependent variable. Considering that the positive coefficient of high rank variable in both years is larger significantly than the low rank variable (the difference in 2011 is about 47 units and in 2012 is about 38 units), ranking of the fund has a positive effect on sensitivity of investors towards fund's performance. Therefore, hypothesis 3 is confirmed.

Testing hypothesis 4

Hypothesis 4 is as follows:

Hypothesis 4: Fund ranking is effective on sensitivity of investors towards the fund's price.

\begin{tabular}{|c|l|c|c|c|c|}
\hline Year & \multicolumn{1}{|c|}{ Variable } & Coefficient & Standard deviation & t-statistic & Error level \\
\hline \multirow{2}{*}{2011} & $\begin{array}{l}\text { Constant } \\
\text { coefficient }\end{array}$ & -50.72 & 4.20 & -12.08 & 0.000 \\
\cline { 2 - 6 } & Low & 20.92 & 1.13 & 18.56 & 0.000 \\
\cline { 2 - 6 } & High & 67.82 & 4.23 & 16.04 & 0.000 \\
\cline { 2 - 6 } & Coefficient of determination & 0.31 & F-statistic & 59.3 \\
\cline { 2 - 6 } & $\begin{array}{l}\text { Adjusted coefficient of } \\
\text { determination }\end{array}$ & 0.30 & $\begin{array}{c}\text { Prob (F- } \\
\text { statistic) }\end{array}$ & 0.000 \\
\hline
\end{tabular}




\begin{tabular}{|c|c|c|c|c|c|}
\hline Year & Variable & Coefficient & Standard deviation & t-statistic & Error level \\
\hline \multirow{5}{*}{2012} & $\begin{array}{l}\text { Constant } \\
\text { coefficient }\end{array}$ & 25.94 & 3.04 & & 0.000 \\
\hline & Low & 69.39 & 2.21 & & 0.000 \\
\hline & High & 107.80 & 0.92 & & 0.000 \\
\hline & \multicolumn{2}{|c|}{ Coefficient of determination } & 0.50 & F-statistic & 2.309 \\
\hline & \multicolumn{2}{|c|}{$\begin{array}{l}\text { Adjusted coefficient of } \\
\text { determination }\end{array}$} & 0.49 & $\begin{array}{l}\text { Prob (F- } \\
\text { statistic) }\end{array}$ & 0.000 \\
\hline
\end{tabular}

Given to the obtained error level for $\mathrm{F}$ statistic for the two years that is close to zero, $\mathrm{HO}$ is rejected and it shows that regression coefficients are not equal to zero simultaneously. Therefore, there is a relationship among independent variables and the dependent variable simultaneously.

Error level of t-statistic for two variables of Mid and High that indicates fund ranking is close to zero in 2011 and 2012 and is less than error level 0.05 . Value of adjusted $R^{2}$ is equal to 0.30 and 0.49 respectively that shows the independent variable explained $30 \%$ and $49 \%$ of changes of the dependent variable. Considering that the positive coefficient of high rank variable in both years is larger significantly than the low rank variable (the difference in 2011 is about 47 units and in 2012 is about 38 units), ranking of the fund has a positive effect on sensitivity of investors towards fund's performance. Therefore, hypothesis 4 is confirmed.

\section{Conclusion}

Given to the results of the above four hypotheses, the effect of ranking on sensitivity of investors towards performance and price of investment funds was confirmed with the difference that price sensitivity is more than performance sensitivity. This is while effectiveness of sensitivity of investors towards performance and price from goodwill was not confirmed for its four representatives. In discussing on sensitivity towards price, the effect of bank, age and inter-group ranking were shown and the effect of age and bank were just confirmed for sensitivity towards performance.

Considering that the relationship between sensitivity of investors towards performance and price of funds with ranking and goodwill was investigated in the present study and no similar research has been conducted in Iran, it is impossible to compare the obtained results with similar internal studies. Comparing the results of this study with Musto and Christoffersen's research (2002) showed that the results are not consistent. It means that sensitivity of investors towards performance in the above-mentioned research is more than sensitivity towards price and this is not confirmed in this study. Although results of Yan and Huang's research (2007) confirm the relationship among sensitivity of investment flows, age and size like this study but sensitivity towards performance is reported higher. Results of the present study are consistent more with Navone (2012), because the relationship between ranking and goodwill with 
sensitivity of investment flows towards performance and price has been confirmed in both studies. Similarly, price sensitivity was more than performance sensitivity in both studies. Differences between the two studies are as the following. The relationship among all variables of goodwill and sensitivities were confirmed in Navone's study; while the relationship of size variable was not confirmed in the present study. Navone, however, measured the process of performance and price sensitivities through a 20-year time period and compared them but it was not possible in this study to calculate the process and mean of sensitivities of investment flows towards performance and price and compare them because of the newly-established funds in Iran and their maximum four-year age.

\section{References}

Choi, J., Laibson, D., Madrian, B., (2010). Why Does The Law of One Price Fail? An Experiment on Index Mutual Funds. Review of Financial Studies 23 (4), 1405-1432.

Christoffersen, S., Musto, D., (2002). Demand Curves And The Pricing of Money Management. Review of Financial Studies 15 (5), 1499-1524.

Gil-Bazo, J., Ruiz-Verdं, P., (2009). The Relation Between Price And Performance In The Mutual Fund Industry. Journal of Finance 64 (5), 2153-2183

Huang, J., Wei, K., Yan, H., (2007). Participation Costs And The Sensitivity of Fund Flows to Past Performance. Journal of Finance 62 (3), 1273-1311.

Navone,M., (2012) .Investors Distraction And Strategic Repricing Decisions.Journal of Banking \& Finace 36,1291-1303.

Saeidi, A; Saeidi, H. (2012). Relationship between capital flow of investment funds and market return: Evidences from Tehran Stock Exchange. Journal of Financial Studies, 32

Saeidi, A. et al. (2011). Effective factors on return of investment funds in Tehran Stock Exchange. Quarterly Journal of Securities Exchange, 3 (10)

Saeidi, A; Moghadassian, I. (2011). Performance assessment of shared investment funds in Iran. Quarterly Journal of Securities Exchange, 3 (9)

Pourzamani, Z. et al. (2011). Studying the effect of some managerial and environmental factors on return of shared investment funds in Iran. Journal of Management Studies, 86 Wilcox, R., 2003. Bargain Hunting or Star Gazing? Investors' Preferences For Stock Mutual Funds. Journal of Business 76 (4), 645-663. 